\title{
The Effect of Oral Health Care Interventions on Oral Self Care Practices of the Institutionalized Older Adults
}

\author{
Neamit Ibrahim Elemam Ahmed Elashri, Assistant Lecturer \\ Gerontological Nursing, Faculty of Nursing, Mansoura University \\ Nagwa Abd El-Fattah Ibrahim, Professor \\ Gerontological Nursing, Faculty of Nursing, Alexandria University \\ Amany Mohamed Shebl, Assistant Professor \\ Medical Surgical Nursing, Faculty of Nursing, Mansoura University \\ Soad Hassan Abd Elhameed, Lecturer \\ Gerontological Nursing, Faculty of Nursing, Mansoura University
}

\begin{abstract}
One of the major criteria of successful aging is maintaining a natural, healthy, functional dentition throughout life. However, the oral health of older adults is far from the optimal. Treatment needs are high due to edentulism, caries and periodontal diseases resulting in impaired oral functions. The etiology of many dental diseases is influenced by oral self care practices and lifestyle factors. Therefore; professionally organized oral health self-care practices are very important for institutionalized older adults. Objective: Determine the effect of oral health care interventions on oral health self care practices of institutionalized older adults. Settings: Dar El-Amal in Mansoura city, Ras El bar elderly home in Ras El bar city, Dar El-Walaa in meet khamr city and Dar El saada in Tanta city. Subjects: 70 institutionalized older adults aged 60 years and above have no artificial teeth, have normal cognitive and have no depression. Tools: Five tools were used: Older Adults Socio Demographic and Clinical Data Structured Interview Schedule, the Mini Mental State Examination (MMSE) Scale, the Geriatric Depression Scale (GDS) Short Form, Older Adults' Knowledge Related to Oral Health Structured Interview Schedule, and Older Adult's Oral Self Care Practices. Results: positive improvement in the level of oral self care practices of subjects in the study group after implementation of the study intervention with a statistically significant difference between the two groups. A higher mean score of oral self care practices of subjects in the study group was found in males than females, in those with higher education than those with lower education and in those with higher monthly income than those with lower monthly income. Conclusion: Improved oral health knowledge and oral self care practices among the majority of subjects in the study group. A higher mean score of oral self care practices was found in males than in females, in those with higher education and in those with higher monthly income. A positive direct relationship was found between the oral health knowledge of subjects in the study group and their oral self-care practices. Recommendations: All institutionalized older adults should be follow periodic dental examination regularly with daily oral self care practices.
\end{abstract}

Keywords: Oral health, Oral self care practice, Oral health knowledge, Institutionalized older adults. 


\section{Introduction}

Oral health of older adults is a basic need that is increasingly neglected with advanced age, debilitation and limited mobility. One of the reasons for this neglect may be the general assumption that older adults are edentulous. Older adults themselves may believe that losing their teeth is a natural consequence of growing old. Oral health is important at all stages of life to keep teeth longer and stronger. Teeth loss is not a natural part of the aging process but, rather is a problem that occurs over time and it is most evident in later years. According to oral health experts, a lot of people suffer from poor oral health without being aware of it and at times it can impact a person's quality of life. It is a fundamental component in the overall well-being and quality of life for elders living in long-term care facilities ${ }^{(1-3)}$.

Effective oral care interventions must not only involve recognizing the importance of oral health but giving oral hygiene the same priority as other care practices in longterm care settings ${ }^{(4)}$. Weakened oral health due to neglect of oral self care practices and due to reduced oral health care utilization is already present when older adults are still community dwelling, many older adults are in need of oral health care urgently ${ }^{(5,6)}$.

The international literature increasingly reveals that there is a growing awareness of the necessity to improve oral health care of institutionalized older adults. Advances in oral health care and treatment during the last decades have resulted in a reduced number of edentulous older adults $^{(7)}$. Oral health of institutionalized older adults is often worse than that in the general population and involves increased prevalence of edentulism and numerous unmet dental needs. Previous studies on oral health have found that impairment and poor oral hygiene are more common in older adults, especially who are institutionalized.

Gerontological nurses play a key role in the prevention of disease directly related to poor oral care. Daily care of the teeth and mouth is important for a healthy life and will lead to improved quality of life for older adults. Moreover, improvement in the oral health habits, oral health promotion should be targeted at community dwelling older adults, aiming at positive changes in oral health behavior to prevent teeth loss ${ }^{(8)}$.

Older adults are less likely to have received preventive education early in life when the establishment of oral hygiene habits is most efficacious and are more resistant to change in later life. Oral health care interventions must focus on enhancing older adults perception of the importance of oral health by helping them integrate dental knowledge into their life style and self care practice routine ${ }^{(9,10)}$.

\section{Aim of the Study}

Determine the effect of oral health care interventions on oral health self care practices of institutionalized older adults.

\section{Materials and Method}

\section{Materials}

Design: Quasi experimental design was utilized in this study.

Settings: The study was carried out in four governmental assisted living facilities (elderly homes) namely; Dar El-Amal in Mansoura city and Dar El-Walaa in meet khamr city in Dakahlia governorate, Dar Kebar Elsen in Ras Elbar city in Diameta governorate and Dar Elsaada in Tanta city in Gharbeia Governorate.

Subjects: The EPI info V 7.0 was used to estimate the sample size by using the following parameters: Expected frequency $=$ $15 \%$, Acceptable error: alpha error $=5 \%$, Beta error $=20 \%$, Study power $=80 \%$, Confidence Coefficient $=95 \%$. Based on these parameters the required sample size in the proposed study was 70 older adults. The study subjects were divided into two groups 35 subject in each, one experimental and one control group, the study (experimental) group was selected from Dar El-Amal in 
Mansoura city and Ras El bar elderly home in Ras El bar city and the control group was selected from Dar El-Walaa in meet khamr city and Dar El saada in Tanta city.

\section{Tools:}

Tool I: Older Adults Socio Demographic and Clinical Data Structured Interview Schedule

This tool was developed by the researcher based on review of relevant literature; it includes data such as; age, sex, level of education, marital status, occupation before retirement, income, length of stay in elderly home, older adults satisfaction about the elderly home. Self rated current general health and oral health status, dental visit frequency and date of last visit and its reason, presence of oral and other medical diseases and medications.

\section{Tool II: The Mini Mental State Examination (MMSE) Scale (1975) ${ }^{(11)}$}

This scale was developed by Folstein et al (1975). It was translated into Arabic language and validated by El Okel $(2002)^{(12)}$ it is originally designed to assess the cognitive function of older adults. The scale includes five categories of cognitive functions. They are categorized into three levels of cognitive impairment: normal cognitive function, mild and severe cognitive impairment. The scale total score is 30 grades classified as: score from 24 to 30 is assigned for those who have normal cognitive function, score from 18 to 23 is assigned for those who have mild cognitive impairment and score from zero to 17 is assigned for those who have severe cognitive impairment ${ }^{(13)}$.

Tool III: The Geriatric Depression Scale (GDS) Short Form (1986)

This scale was developed by Sheikh\&Yesavage (1986) ${ }^{(14)}$ It is originally designed to assess the presence of depression and general wellbeing of older adults. It was translated into Arabic and approved to be valid and reliable $\left(\mathrm{r}_{=}=0.70\right)$ by Elhuseiny (2013). ${ }^{(15)}$ The scale includes fifteen questions. For ten (10) questions, a positive answer indicates the presence of depression and negative answer for the remaining five questions (question numbers $1,5,7,11 \& 13)$ also indicates depression. When the response to a question is yes a score of one is allotted when the response is no a score of zero is allotted. The older adult chooses the answer either yes: one (1) or No: zero (0) for how he/ she have felt over the last week. The total score for the tool is fifteen; items are summed for total score. As score from zero to 4 is assigned for those who have no depression, a score from 5 to 8 is assigned for those who have mild depression, and a score from 9 to 11 is assigned for those who have moderate depression and a score from 12 to 15 is assigned for those who have severe depression.

Tool IV: Older Adults' Knowledge Related to Oral Health Structured Interview Schedule

This tool was developed by the researcher after reviewing the relevant literature. It was used to assess the knowledge of the study subjects before and after the implementation of the proposed oral health care interventions. It was approved to be valid by a jury member in the related fields. It includes questions about oral health such as healthy oral cavity criteria, normal age related changes affecting the oral cavity, risk factors for oral diseases, most common periodontal disease and measures to maintain healthy oral cavity. The total numbers of questions are twelve (12), for each question several correct answers are allotted, the number of correct answer ranges from four to eight, each correct answer is allotted one grade with the total grade for all question ranges from four to eight. Each wrong answer to the same question takes a score of zero (0) grade and the same for an answer did not know. The scores for older adult's oral health knowledge were depended on the numbers of grades the older adult obtained regarding all questions. The total grade was computed out of seventy (70) grades. 


\section{Tool V: Older Adult's Oral Self Care Practices}

This tool includes two parts:

\section{Part One: Oral Self Care Practices Structured Interview Schedule}

This tool was developed by the researcher based on review of relevant literature. It was used to assess the oral self care practices of the study subjects before and after the implementation of the proposed study interventions. It was approved to be valid by jury members in the related fields. It includes questions about teeth brushing habits, teeth flossing habits, fluid and dietary intake and periodic dental examination. Includes twenty one (21) questions for older adults with natural teeth, nineteen (19) questions multiple choice, and two (2) closed ended questions. The multiple choice questions answer ranges from three to six answers, correct answer for each question gets a score of one grade, while wrong answer gets a score of zero. The scores depended on the number of grades the older adult obtained regarding all questions. The total grade was computed out of twenty one (21) grades.

\section{Part Two: Oral Self Care Practices Observation Checklist}

This part was adapted by the researcher based on review of current literature. It was used to assess the oral self care skills of the study subjects before and after the implementation of the study interventions. It includes three (3) procedures for older adults with natural teeth, the three procedures are:

\section{Procedure One: Teeth Brushing}

Teeth brushing procedure was approved to be valid by jury members in the related fields. It was used to assess teeth brushing skills of the study subjects before and after the implementation of the proposed study interventions. It consists of six (6) steps. The performance of the study subjects of each step of the procedure was evaluated on a three point likert scale ranging from completely manage the step to unable to manage the step at all. A score of two (2) is allotted for older adults who is able to completely manage the step. A score of one (1) is allotted to older adults who is able to partially manage the step and zero score is allotted to older adults who is unable to perform the step at all. The total grades were computed out of twenty twelve (12) grades.

\section{Procedure Two: Teeth Flossing}

Teeth flossing procedure was approved to be valid by jury members in the related fields. It was used to assess teeth flossing skills of the study subjects before and after the implementation of the proposed study interventions. It consists of six (6) steps. The performance of the study subjects of each step of the procedure was evaluated on a three point likert scale ranging from completely manage the step to unable to manage the step at all. A score of two (2) is allotted for older adults who is able to completely manage the step. A score of one(1) is allotted to older adults who is able to partially manage the step and zero score is allotted to older adults who is unable to manage the step at all. The total grades were computed out of twenty twelve (12) grades.

\section{Procedure Three: Oral Cancer Self Examination}

Oral cancer self examination procedure was approved to be valid and reliable by (The National Cancer Institute (2009) ${ }^{(16)}$ It was used to assess oral cancer self examination skills of the study subjects before and after the implementation of the proposed study interventions. It consists of sixteen (10) steps. The performance of the study subjects of each step of the procedure was evaluated on a three point likert scale ranging from completely manage the step to unable to manage the step at all. A score of two (2) is allotted for older adults who is able to completely manage the step. A score of one (1) is allotted to older adults who is able to partially manage the step and zero score is allotted to older adults who is unable to manage the step at all. The total 
grades were computed out of twenty twelve (20) grades.

\section{Method}

- An official letter was issued from the Faculty of Nursing, Al Mansoura University and forwarded to the director of each residential home administrator separately in order to obtain his approval to carry out the study.

- Tool I, IV, V (part one and two) was developed by the researcher based on review of relevant literature and revised by seven experts in the field of gerontological and medical surgical nursing at faculty of nursing in Alexandria and Al Mansoura University, and oral health at the faculty of dentistry, as a jury to test its content validity and feasibility and necessary modification were done.

- A pilot study was carried out on seven (7) older adults $(10 \%$ of the study sample) selected from the Dar El Amal elderly home in Al Mansoura city, through elderly home visits to test and ascertain clarity and feasibility of the study tools and the necessary modifications were done. The older adults who included in the pilot study were excluded from the study sample.

- Tool II and III were used in Arabic version for selection of the study subjects who fulfill the criteria of the study.

- The proposed study interventions were developed by the researcher based on the reviewing of the relevant literature. The proposed study interventions included knowledge and practices required for maintain good oral health, it covered items related to the aging changes in the oral cavity, risk factors of oral diseases, most common oral diseases in older adults, fluid and dietary habits, general measures to promote healthy oral cavity and skills of teeth brushing, teeth flossing and oral cancer self examinations. Written in a simple Arabic language with colored pictures and large sized font to accommodate age-related visual changes to enhance the learning process.

- The researcher used to go to the elderly homes included in the study settings following a certain schedule.

- Each study subject in both the experimental and the control groups was interviewed individually by the researcher at his/her room or in living room of the home starting from 10 am to $5 \mathrm{pm}$. The researcher used to introduce herself and explain the purpose of the study. Then a verbal consent from each study subject to participate in the study was obtained. The researcher assessed each study subjects using study tools; I, IV \& V (pre-test). The necessary information took nearly 25-30 minutes.

- Photographs were taken for oral cavity for each interviewed elders in both groups after take his or her permission; these picture help in visualizations of data.

- The proposed oral health care interventions were conducted on group basis, each group ranged from three to five (3-5) older adults, the interventions were covered in four sessions, two session for provision of knowledge and two sessions for practice, two sessions weekly for two weeks. Each week (one session of knowledge and the other practice session) the duration for each session took about 30 minutes approximately.

- Oral care packages were prepared and disturbed to each older adult in the study group; it included (Dental floss, tooth brushes, mouth rinse, towels, tongue depressor, toothpaste and mirror).

- Teaching methods included lectures, role playing, real life demonstration redemonstrations and discussion. Teaching materials included PowerPoint presentation, illustrated picture, oral care procedure videos and oral health care intervention Booklet (handout). 
- Before starting of each session; older adults were asked questions related to the topic discussed in the previous session to identify their understanding; misses or unclear points were re-emphasized by the researcher. Then a summary of the previous session was started to help older adults to refresh their information's.

- The researcher follow the teaching strategies for elderly by using simple ,concise and clear language in presentation, large printed materials and at the end of each session a brief summary about the important point was given to older adults.

- The researcher makes elderly home visit twice /month and regular telephone calls for older adults in the study group to encourage them to practice of oral care procedure (teeth brushing, teeth flossing and oral self-examinations) for two months after implementation of the program.

- The follow-up visit was found to be very worthy as some elders had misunderstandings of the messages and some elders had even forgotten what we taught them. Without the follow-up visit, the results would not be so significant.

- Reassessment of each study subject was done three times to evaluate the effect of the proposed oral health care interventions. This was done immediately after the implementation of the interventions, then the second reassessment after 3 months, followed by the third assessment after six (6) months.

\section{Ethical considerations:}

A written consent from the study subjects to participate in the study was being obtained after explanation of the study purpose. Privacy and anonymity of the study subjects and confidentiality of the collected data were maintained. The right to withdraw at any time was assured.

\section{Statistical Analysis}

After data were collected, they were coded and transferred into special design formats, so as to be suitable for computer feeding. The Statistical Package for Social Sciences "SPSS" software version 20.0 was utilized for data analysis and tabulation. The 0.05 level was used as the cut off value for statistical significance and the following statistical measures were used. Descriptive statistics: Count and percentage. Analytical statistics which include: Chi Square (x)2, Independent sample t-test, Paired sample ttest, Wilcoxon signed ranked test and Ftest(One Way ANOVA).

\section{Results}

Table (1) illustrates that, $82.9 \%$ of the study subjects in both groups are aged from 60 years to less than 75 years with a mean of $69.83 \pm 6.26$ years for the study group and $68.66 \pm 5.64$ years for the control group. As for sex, males constituted $54.3 \%$ of subjects in the study group and $48.6 \%$ of subjects in the control group. With regard to the marital status, widowhood was found in $71.4 \%$ of subjects in the study group compared to $42.9 \%$ of subjects in the control group. As for the educational level, illiteracy was prevailing among $31.4 \%$ of subjects in the study group and $45.7 \%$ of subjects in the control group. Concerning the occupation prior to retirement, $31.4 \%$ of subjects in the study group and $37.1 \%$ of subjects in the control group are housewives. $42.9 \%$ of subjects in the study group and $31.4 \%$ of subjects in the control group were employees. As for the monthly income reported by the study subjects ranges from less than 200 up to 400 L.E, $74.3 \%$ of subjects in the study group and $62.9 \%$ of subjects in the control group reported 400 LE per month and more. As for the source of income, $71.4 \%$ of subjects in the study group and $60.0 \%$ of subjects in the control group reported the source of income is pension.

It can be observed from table (2) that, cardiovascular disorders were reported by $85.7 \%$ of subjects in the study group and 
$88.6 \%$ of subjects in the control group. Musculoskeletal disorders were found in $48.6 \%$ of subjects in the study group and $42.9 \%$ of subjects in the control group. Endocrine disorders were reported by $57.1 \%$ of subjects in the study group and $68.6 \%$ of subjects in the control group.

Table (3): Regarding to the natural teeth condition, $88.6 \%$ of subjects of the study group compared to $82.9 \%$ of subjects in the control group have partial teeth loss, the total mean score of teeth loss was $15.10 \pm 11.8$ teeth in males' subject's and $7.93 \pm 7.79$ teeth for females. As for the control group the total mean score of teeth loss in males are15.64 \pm 13.02 teeth compared to in females are $15.72 \pm 10.35$ teeth. As for number of remaining teeth in the study subjects in both group, it can observed that $65.7 \%$ of subjects in the study group and $48.6 \%$ in the control group have $\geq 20$ remaining teeth in their oral cavity.

Table (4): Concerning dental visits and frequency, $60.0 \%$ of subjects in the study group and $42.9 \%$ of subjects in the control group do not visit the dentist at all, while $40.0 \%$ of subjects in the study group and $54.3 \%$ of subjects in the control group visit dentist when they having a problem. As for the reasons of last dental examination, $45.0 \%$ of subjects in the control group and $35.7 \%$ of subjects in the study group reported visit dental clinic for teeth extractions. Toothache was reported by $28.6 \%$ of subjects in the study group and $20.0 \%$ of subjects in the control group. With regard to reason of not having dental examination, it can be observed that $82.9 \%$ of subjects in the study group and $91.4 \%$ of subjects in the control group not perceive the need and importance of dental visit while need to transportations was found in $91.4 \%$ of subjects in the study group and $82.9 \%$ of subjects in the control group.

Table (5): As for teeth brushing, 28.6\% of subjects in the study group and $37.1 \%$ of subjects in the control group do not brush their teeth, $37.1 \%$ of subjects in the study group and $25.7 \%$ of subjects in the control group brush their teeth once per day. $11.4 \%$ of subjects in the study group and $8.6 \%$ of subjects in the control group brush their teeth twice per day. $14.3 \%$ of subjects in the study group and $22.9 \%$ of subjects in the control group brush their teeth after each meal. $8.6 \%$ of subjects in the study group and $5.7 \%$ of subjects in the control group brush their teeth during ablution for pray. With regard to teeth cleaning material, $20.0 \%$ of subjects in the study group and $11.4 \%$ in the control group use miswak. $8.6 \%$ of subjects in the study group and $17.1 \%$ of subjects in the control group use salty water. $5.7 \%$ of subjects in the study group and $2.9 \%$ of subjects in the control group use dental floss. $5.7 \%$ of subjects in the study group and non in the control group use toothpicks. As for the type of mouth wash, $31.4 \%$ of subjects in the study group and $34.3 \%$ of subjects in the control group do not use mouth wash, $57.1 \%$ of subjects in the study group and $48.6 \%$ of subjects in the control group use salty warm water as a mouthwash. Regarding teeth flossing, $85.7 \%$ of subjects in the study group and $91.4 \%$ in the control group do not floss their teeth. Regarding the dietary pattern, $80.0 \%$ of subjects in the study group and $77.1 \%$ of subjects in the control group do not follow therapeutic regimens. As for eating difficulties, $34.3 \%$ of subjects in the study group and $28.6 \%$ of subjects in the control group do not have difficulty in eating any type of food. $17.1 \%$ of subjects in both groups have difficulty in eating fresh vegetables and fruits while $40.0 \%$ of subjects in the study group and $42.9 \%$ of subjects in the control group have difficulty in eating fresh vegetables, fresh fruits and meat. With regard to the amount of fluid intake per day, $54.3 \%$ of subjects in the study group and $57.1 \%$ of subjects in the control group drink one liter of fluid per day.

Table (6): Regarding the teeth brushing observation of the study subjects, a statistically significant difference in the ability of subjects in the study group to manage teeth brushing was found before the interventions and immediately after it $\left(Z_{=}-\right.$ 5.052, $\mathrm{P}=0.000$ ) As for the teeth flossing a statistically significant difference in the 
ability of subjects in the study group to manage teeth flossing before the intervention and immediately after it $\left(Z_{=-}\right.$ $5.445, \mathrm{P}=0.000)$. No statistically significant difference was found the ability of subjects in the control group to manage teeth flossing before the intervention and immediately after it $\left(\mathrm{Z}_{=}=1.342, \mathrm{P}=0.180\right)$. Regarding the oral cancer self examination observations, a statistically significant difference was found in the ability of subjects in the study group to manage the oral cancer self examination before the intervention and immediately after it $\left(Z_{=}=-\right.$ 5.477, $\mathrm{P}=0.001$ ). No statistically significant difference was found in the ability of subjects in the control group to manage the oral cancer self examination before the intervention and immediately after it $\left(Z_{=-}\right.$ 2.000, $\mathrm{P}=0.146$ ).

Table (7): The difference is statistically significant between the total mean score of oral health knowledge of subjects in the study group before and immediately after the intervention $(\mathrm{P}=0.000)$. A statistically significant difference is found in the total mean score of oral health knowledge of subjects in the study group before and three months after the intervention $\left(\mathrm{P}_{=} 0.000\right)$. $\mathrm{A}$ statistically significant difference is found between the total mean score of oral health knowledge of subjects in the study group before and six months after the intervention $(\mathrm{P}=0.000)$. No statistically significant difference was found in the total mean score of the oral health knowledge of subjects in the control group before the intervention and after it.

Table (8): Three months after the intervention, a statistically significant difference is found in the total mean score of the oral self care practices of subjects in the study group before and three after the intervention $\quad(\mathrm{P}=0.000)$. Moreover a statistically significant difference is found in the total mean score of the oral self care practices of subjects in the study group before and six after the intervention $(\mathrm{P}=0.000)$. No statistically significant difference was found in the total mean score of the oral self care practices of subjects in the control group before the interventions and six months after it $(\mathrm{P}=0.199)$.

Table (9): As for the relation between age of subjects in the study group and their total mean score of the oral self care practices six months after the intervention, no statistically significant difference was found between different age groups of institutionalized older adults of the study group in their total mean score of oral self care practices $(\mathrm{P}=0.606)$. With regard to the relation between sex of subjects in the study group and their total mean score of the oral self care practices, Six months after the intervention the mean of the oral self care practices of male's subjects in the study group was $11.47 \pm 4.71$ compared to $9.31 \pm 2.24$ of female's subjects in the same group with a statistically significant difference $(\mathrm{P}=0.015)$. The level of the oral self care practices was found to be good in male's subjects than female's subjects in the study group. Moreover the level of education of institutionalized older affect significantly their oral self care practices, as it was observed that improved the oral self care practices of institutionalized older who had university educational level than illiterate and primary level three months $(\mathrm{P}=0.000)$ and six months $(\mathrm{P}=0.000)$ after the intervention. As regard to the relation between the monthly income of subjects of the study group and their oral self care practices, Six months after the intervention, the mean of the oral self care practices of subjects of the study group was $6.75 \pm 2.99$ for elders with monthly income from more than 200 L.E to less than 300 L.E compared to $12.81 \pm 4.19$ for elders with monthly income more than 400 L.E with a statistically significant difference $(\mathrm{P}=0.059)$. Finally; the marital status of institutionalized older in the study group had no effect on their oral self care practices before and after implementation of the interventions.

Table (10): This table shows that, before the implementation of the intervention a significant relation was found between the total mean score of the oral health knowledge $(8.43 \pm 4.70)$ and the total mean 
score of the oral self care practices (4.97 \pm 2.49$)$ evidenced by $(0.401, \mathrm{P}=0.017)$. Three months after the intervention a positive highly significant relation is observed between the total mean score of the oral health knowledge $(25.60 \pm 11.96)$ and the total mean score of the oral self care practices $(13.86 \pm 4.75)$ evidenced by (0.854, $\quad \mathrm{P}=0.000)$. Six months after the intervention a highly significant relation is found between the total mean score of the oral health knowledge $(19.80 \pm 9.56)$ and the total mean score of the oral self care practices $(11.03 \pm 4.06)$ evidenced by $(0.770$, $\mathrm{P}=0.000$ ). A positive direct relationship was found between the oral health knowledge of subjects in the study group and their oral self-care practices. The higher level of the oral health knowledge, the better the oral self care practices of subjects in the study group.

\section{Discussion}

A longer life should not mean simply added quantity. A longer life should mean a better life. As institutionalized elders increase, we must be prepared to meet their needs for better quality of life. Theoretical explanations related to the effect of oral health on the quality of life have been well documented in the literature ${ }^{(17)}$. Quality of life is positively correlated with general health which is correlated positively with oral health and better oral self care practice $^{(18)}$.

As for age of the study subjects, the majority of subjects in both the study and control groups are young old (table1). Similar supporting studies for this result were conducted in Alexandria Egypt, Saudia Arabia, Nigeria and Malaysia respectively ${ }^{(19-22)}$. In respect to sex, more than one half of subjects in the study and control groups are males with no statistically significant difference between both groups (table1). This finding may be related to the social changes associated with the advancing age as most of older adult males are used to receive assistance from spouses and children thus transferring to a residential home ensure the continuity of assistance. This finding is consistent with a study conducted in Alexandria Egypt which reported that the majority of her study subjects are males ${ }^{(19)}$ and the same finding was reported a study conducted in Saudi Arabia by Al-Shehri (2012) ${ }^{(21)}$.

Regarding the educational level, the majority of female subjects in the study and control group are illiterate compared to males who have either primary, secondary and university education with no statistically significant difference between both groups (table 1). This may be explained by the high prevalence of illiteracy in Egypt. This is in agreement with a study done by Juliana, Taiwo, et al (2012) and Abd Elhameed (2005) ${ }^{(22,23)}$ and corresponds to the finding of study conducted in Alexandria by Hawash (2006) who reported that illiteracy was prevailing among their residents of elderly homes ${ }^{(19)}$.

On the same line another study done by Evren, et al (2011) reported that the majority of residents in both groups were illiterate with no statistically significant difference between both groups. ${ }^{(24)}$ With regards to the marital status, the present study showed that the majority of subjects in both groups are widows and widowers with a statistically significant difference between both groups (table 1). However, marital status in general in this study was not a factor that affected any of the outcomes of the present study at all. This finding is supported by El Husseini (2008) who found that the majority of institutionalized elders are widows and widowers $^{(25)}$. Another study done by Branch \& Jetten concluded that widowed and divorced older persons have a higher probability of institutionalization than their married counterparts ${ }^{(26)}$.

The present study revealed that that the total mean score of teeth loss of subjects in the study group was higher $(15.10 \pm 11.8$ teeth) in males' subjects than $(7.93 \pm 7.79$ teeth) females subjects (table 3). This finding may attributed to that males neglect to brush their teeth during activities of daily living, being smokers and drinks more coffee and tea in early adulthood compared 
to females taking care of their body image and self esteem as their teeth is a part of their appearance and beauty. This result is very close to those reported by Christensen, Petersen, et al (2003) that males have higher teeth loss rate than females ${ }^{(27)}$. On contrast with this result the finding of a study done in turkey (2011) who found that females had a higher total teeth loss frequency when compared to males ${ }^{(28)}$.

As for teeth condition, the majority of subjects in both groups had partial teeth loss while far fewer of subjects in both groups had complete teeth loss with no statistically significant difference between both groups (table 3). This finding is in accordance with the result obtained in Egypt at 1999, which reported the high prevalence of edentulism among the institutionalized elders who had an average number of remaining teeth varied from 7.5 to 14 teeth $^{(29,30)}$. In the same line a study conducted in Turkey ${ }^{(17)}$. On the opposite side previous studies reported that advanced age and female gender are reported to correlate with higher rate of teeth $\operatorname{loss}^{(31,32)}$. The present study revealed that more than one quarter of subjects in the study group do not brush their teeth. The minority of subjects in both groups brush their teeth twice per day (table 5). This finding may be due to most of elders forgetting and not used to maintain oral health unless having a problem. Moreover some older adult perceive teeth loss as a consequence and part of aging process. Similar finding were supported and confirmed by a study done in Egypt (1999) and In contrast with Juliana, Taiwo\& Ibiyemi, et al (2012) reported that the majority of their subjects clean their teeth twice daily. ${ }^{(22,30)}$.

Regarding mouth rinse, the present study revealed that nearly one half of subjects in both groups use salty warm water as mouthwash with no statistically significant difference between the two groups (table 5). This is in agreement with Hawash, (2006) who reported that over one half of her subjects cleansed their teeth by either water and soap or water and salt ${ }^{(19)}$. In contrast with another the finding of a study done by Zhu, Petersen, Wang et al (2005) reported that less than one quarter of their participant rinsed their mouth with tea and few percent use salt and fluoridated water $^{(33)}$.

As for teeth flossing, the majority of subjects in both groups do not floss their teeth (table 5). This may be due to teeth flossing need manual skills in holding and using dental floss and many of elder do not able to hold dental floss as they have musculoskeletal changes in their hand. Little percentage of them uses toothpicks in flossing after meals with no statistically significant differences between two groups. On the same line a study carried out in Alexandria by Hawash reported that a few percentages of her studied older adults were using Miswak and dental flossing ${ }^{(19)}$. Another study done by Zhu et al reported that a few respondents use dental floss and toothpicks after meals. On the same line to the present result a study conducted in Brazil $^{(33,34)}$.

Dental visit pattern is a major contributing factor that affects the institutionalized older adult's oral health status. In the present study nearly two thirds of subjects in the study group do not visit dentist compared to nearly one half in the control group. While nearly one half in each group visits dental clinic when problems occurs with no statistically significant difference between the two groups (table 4). This finding can be explained by older adult residing in elderly homes far from dental clinics and facing transportation difficulties in attaining dental clinic due to the effect of aging process, no caregiver, long time of waiting in dental clinic, those entire factors may contribute to infrequently elderly dental clinic visit. On the same line a study conducted in Alexandria, Egypt by AboulAzm (1986) reported that the elderly tend to use dental services less frequently also they did not saw dentist for other than emergency treatment ${ }^{(35)}$. This result is concordant with other studies ${ }^{(22,28,36)}$.

The present study showed a positive improvement in the level of oral health knowledge of subjects in the study group 
after implementation of the study intervention compared to the level of oral health knowledge of subjects in the control group with a statistically significant difference between the two groups (table 7). This is in consistent with a study done in Japan (2006) reported that their subjects in the study group demonstrated a significant improvement in oral health knowledge compared to the control group after the implementation of the study interventions ${ }^{(37)}$. On the same line a study done by Zini, Slutzky \& Vered (2013) reported that the majority of their subjects reported higher mean score of oral health knowledge after the implementation of the intervention educational plan ${ }^{(38)}$. Other studies reported the same finding ${ }^{(39-42)}$.

With regard to the oral self care practices observation, Immediately after the implementation of the study interventions, the majority of subjects in the study group are completely able to manage teeth brushing, teeth flossing and oral cancer self examination procedures with a statistically significant difference between before the interventions and immediately after it (table 6 ). It could be assumed that most all of the study subjects had been insufficiently informed about preventive dental care skills and are not aware of the importance of teeth brushing and its role in maintaining healthy oral cavity but after implementations of the study interventions the majority of subject in the study group demonstrated ability to manage of all oral self care practices procedures completely. These findings emphasize the importance of older adult's commitment to oral self-care procedures. In the same line a study carried out in Japan revealed that most of their respondents reported compliance with self-care advice especially teeth brushing and teeth flossing with a statistically significant difference before and after oral hygiene advice ${ }^{(42)}$. Another study done in (2011) reported a marked change in the total mean score of the oral self care practices procedures of their subjects teeth brushing, teeth flossing and oral cancer self examination respectively after their practical sessions ${ }^{(43)}$.
The present study showed a positive improvement in the level of oral self care practices of subjects in the study group after implementation of the study intervention compared to the subjects in the control group with a statistically significant difference between the two groups (table 8). In consistent with this result, a study done by Cheung, Tong \& Lum (2006) who reported that one week after the study, the subject of the control group reported the same oral self care habits while the subject of in the intervention group, the percentage of people who reported appropriate oral self-care habits had uniformly increased ${ }^{(37)}$. Another study conducted in Jerusalem Israel reported that their studied elders after six months reported a statistically significant good finding in oral self care habits post their interventional $\operatorname{plan}^{(38)}$. In contrast to the present finding a study done by Komulainen, Ylöstalo \& Syrjälä, et al (2013) reported that the participants in both the intervention and control groups had better dental self care at the two year follow-up than at the baseline ${ }^{(44)}$.

A higher mean score of oral self care practices of subjects in the study group was found in males than females of subjects in the study group (table 9). This finding may be due to males had better educational level and income than females, those factors may be responsible for this difference. This result is congruent with findings of a study done by Elhuseini, (2008) who reported that males had a slightly higher self care mean score than females ${ }^{(25)}$. On the same line, another study conducted in Brazil revealed that females sometimes being negligent about self care actions in relation to the oral cavity $^{(45)}$. On contrast with the present study Artnik, et al, stated that the overall prevalence of poor oral self-care was higher for men than women ${ }^{(46)}$.

Educational level of the study subjects was found to be a factor that affected the level of oral self care practices in this study. A higher mean score of oral self care practices was also found in those with higher education than those with lower education (table 9). This finding may be 
related to the highest percentages of illiteracy among subjects in the study group and support the assumption of older adults with a higher educational background tend to embrace a positive health practices and have access to healthier physical environments. Also lack of education will result in ignorance of good health practices moreover education helps elders to acquire essential skills about oral self care and follow it as healthy life style. On the same line a study done by Abd El Hameed (2005) who reported that no significant relation between age and self care capabilities ${ }^{(23)}$. In this respect Elhuseini (2008) stated that the elders who had a higher level of education reported higher self care capabilities ${ }^{(25)}$. Other studies reported the same finding ${ }^{(27,46,47)}$. The present study revealed a direct positive relation exists between the oral health knowledge of subjects in the study group and their oral self-care practices before and after implementation of the study intervention. The higher level of oral health knowledge, the higher level of and better oral self care practices (table 10). On the same line a study done in India (2012) revealed that the level of dental behavior is in direct positive relationship with the level of dental health knowledge ${ }^{(41)}$. Abdullah, Ali \& Rahiman (2010) reported that oral health knowledge does not necessarily relate to better oral health behavior ${ }^{(48)}$.

\section{Conclusion}

In this study implementation of the oral health care intervention proved to be effective in improving oral health knowledge and oral self care practices of the majority of subjects in the study group. A higher mean score of oral health knowledge was found in the young old age group than the old old age group, in males than in females and in those with higher education. With regard to oral self-care practices, a higher mean score was found in males than females, in those with higher education and in those with higher monthly income. A positive direct relationship was found between the oral health knowledge of subjects in the study group and their oral self-care practices.

\section{Recommendations}

- Raise awareness of institutionalized and community dwelling older adults who attend the out-patient clinics regarding healthy oral self-care practices and periodic dental examinations through nurses and mass media.

- Periodic dental examination to be performed by a dentist for all institutionalized older adults. 
Table (1): Socio-demographic characteristics of the study subjects in both groups.

\begin{tabular}{|c|c|c|c|c|c|c|}
\hline \multirow{2}{*}{ Items } & \multicolumn{2}{|c|}{ Study group } & \multicolumn{2}{|c|}{ Control group } & \multirow{2}{*}{$\mathbf{X}^{2}$} & \multirow{2}{*}{ p-value } \\
\hline & $\mathbf{n}=\mathbf{3 5}$ & $\%$ & $n_{1}=35$ & $\%$ & & \\
\hline $\begin{array}{l}\text { Age (in } \\
\text { year): } \\
\cdot \quad 60- \\
: \quad 75- \\
: \quad 85+\end{array}$ & $\begin{array}{c}29 \\
4 \\
2\end{array}$ & $\begin{array}{c}82.9 \\
11.4 \\
5.7\end{array}$ & $\begin{array}{c}29 \\
6 \\
0\end{array}$ & $\begin{array}{c}82.9 \\
17.1 \\
0.0\end{array}$ & \multirow[t]{2}{*}{2.400} & \multirow[t]{2}{*}{0.301} \\
\hline & \multicolumn{2}{|c|}{$\begin{array}{c}\text { Mean } \pm \text { SD } \\
69.83 \pm 6.26 \text { years }\end{array}$} & \multicolumn{2}{|c|}{$\begin{array}{c}\text { Mean } \pm \text { SD } \\
68.66 \pm 5.64 \text { years }\end{array}$} & & \\
\hline $\begin{aligned} \text { Sex: } & \\
: & \text { Males } \\
: & \text { Females }\end{aligned}$ & $\begin{array}{l}19 \\
16\end{array}$ & $\begin{array}{l}54.3 \\
45.7\end{array}$ & $\begin{array}{l}17 \\
18\end{array}$ & $\begin{array}{l}48.6 \\
51.4\end{array}$ & 0.229 & 0.632 \\
\hline $\begin{array}{cl}\text { Level of education: } \\
\cdot \text { Illiterate } \\
: \text { Primary education } \\
: \text { Secondary education } \\
: \text { University education } \\
\text {. } & \text { Higher education } \\
\end{array}$ & $\begin{array}{l}11 \\
8 \\
6 \\
10 \\
0\end{array}$ & $\begin{array}{c}31.4 \\
22.9 \\
17.1 \\
28.6 \\
0\end{array}$ & $\begin{array}{l}16 \\
16 \\
7 \\
3 \\
7 \\
2 \\
\end{array}$ & $\begin{array}{r}45.7 \\
20.0 \\
8.6 \\
20.0 \\
5.7 \\
\end{array}$ & 4.522 & 0.340 \\
\hline $\begin{array}{cl}\text { Marital status : } \\
\text { : } & \text { Married } \\
: & \text { Widowed } \\
: & \text { Divorced } \\
: & \text { Separated } \\
\text { : } & \text { Single } \\
\end{array}$ & $\begin{array}{c}0 \\
25 \\
5 \\
5 \\
0\end{array}$ & $\begin{array}{c}0.0 \\
71.4 \\
14.3 \\
14.3 \\
0.0\end{array}$ & $\begin{array}{l}2 \\
15 \\
4 \\
10 \\
4\end{array}$ & $\begin{array}{r}5.7 \\
42.9 \\
11.4 \\
28.6 \\
11.4\end{array}$ & 10.278 & $* 0.036$ \\
\hline $\begin{array}{l}\text { Occupation before retirement: } \\
\cdot \text { Housewives } \\
. \quad \text { Employees } \\
\text {. Worker(skilled \& } \\
\text { unskilled) }\end{array}$ & $\begin{array}{l}11 \\
15 \\
9\end{array}$ & $\begin{array}{l}31.4 \\
42.9 \\
25.7\end{array}$ & $\begin{array}{l}13 \\
11 \\
11\end{array}$ & $\begin{array}{l}37.1 \\
31.4 \\
31.4\end{array}$ & 1.449 & 0.836 \\
\hline $\begin{array}{c}\text { Monthly income: } \\
. \quad 200 \\
. \quad 200<300 \\
. \quad 300<400 \\
. \quad 400+\end{array}$ & $\begin{array}{l}0 \\
5 \\
4 \\
26\end{array}$ & $\begin{array}{l}0.0 \\
14.3 \\
11.4 \\
74.3\end{array}$ & $\begin{array}{c}1 \\
8 \\
4 \\
22\end{array}$ & $\begin{array}{r}2.9 \\
22.9 \\
11.4 \\
62.9\end{array}$ & 2.026 & 0.567 \\
\hline $\begin{array}{l}\text { Source of income: } \\
. \text { Pension } \\
. \text { Son's help } \\
. \text { official social assistance } \\
. \text { Owner }\end{array}$ & $\begin{array}{l}25 \\
3 \\
0 \\
7\end{array}$ & $\begin{array}{l}71.4 \\
8.6 \\
0.0 \\
20.0\end{array}$ & $\begin{array}{l}21 \\
7 \\
2 \\
5\end{array}$ & $\begin{array}{r}60.0 \\
20.0 \\
5.7 \\
14.3\end{array}$ & 4.281 & 0.232 \\
\hline
\end{tabular}

Table (2): Clinical data of the study subjects in both groups.

\begin{tabular}{||l|c|c|c|c|c|c||}
\hline \multirow{2}{*}{ Medical history \# } & \multicolumn{2}{|c|}{$\begin{array}{c}\text { Study } \\
\text { group }\end{array}$} & \multicolumn{2}{c|}{$\begin{array}{c}\text { Control } \\
\text { group }\end{array}$} & \multirow{2}{*}{$\mathbf{X}^{\mathbf{2}}$} & \multicolumn{1}{|c|}{$\begin{array}{c}\text { P- } \\
\text { value }\end{array}$} \\
\cline { 2 - 8 } & $\begin{array}{c}\mathbf{n}_{=} \\
\mathbf{3 5}\end{array}$ & $\mathbf{\%}$ & $\begin{array}{c}\mathbf{n}_{=} \\
\mathbf{3 5}\end{array}$ & $\mathbf{\%}$ & & \\
\hline $\begin{array}{l}\text {-Cardiovascular disorders (hypertension\& } \\
\text { heart failure) }\end{array}$ & 30 & 85.7 & 31 & 88.6 & 4.786 & 0.810 \\
\hline $\begin{array}{l}\text {-Musculoskeletal disorders (osteoarthritis\& } \\
\text { osteoporosis) }\end{array}$ & 17 & 48.6 & 15 & 42.9 & 0.230 & 0.631 \\
\hline -Endocrine disorders (diabetes mellitus) & 20 & 57.1 & 24 & 68.6 & 0.979 & 0.322 \\
\hline $\begin{array}{l}\text {-Gastrointestinal disorder (liver cirrhosis } \\
\text { \&peptic ulcer) }\end{array}$ & 9 & 25.7 & 9 & 25.7 & 0.000 & 1.000 \\
\hline -Urological disorders (kidney stones) & 6 & 17.1 & 7 & 20.0 & 0.094 & 0.759 \\
\hline
\end{tabular}


Table (3): Teeth condition of the study subjects.

\begin{tabular}{|c|c|c|c|c|c|}
\hline Items & \multicolumn{2}{|c|}{ Study group } & \multicolumn{2}{|c|}{ Control group } & $\begin{array}{l}X^{2} \\
(p-\end{array}$ \\
\hline \multirow{2}{*}{$\begin{aligned} & \text { Teeth condition: } \\
& \text {. } \text { Completely present } \\
& . \text { Partial loss } \\
& . \text { Complete loss }\end{aligned}$} & $n_{=} \mathbf{3 5}$ & $\%$ & $n_{=}=35$ & $\%$ & \multirow[b]{2}{*}{$\begin{array}{c}1.178 \\
(0.555)\end{array}$} \\
\hline & $\begin{array}{c}0 \\
31 \\
4\end{array}$ & $\begin{array}{c}0.0 \\
88.6 \\
11.4\end{array}$ & $\begin{array}{c}1 \\
29 \\
5\end{array}$ & $\begin{array}{c}2.9 \\
82.9 \\
14.3\end{array}$ & \\
\hline \multirow{3}{*}{ Mean of partial teeth loss } & \multicolumn{2}{|c|}{$11.83 \pm 10.66$} & \multicolumn{2}{|c|}{$15.69 \pm 11.55$} & \multirow{3}{*}{$\mathrm{P}=0.151$} \\
\hline & Male & Females & Male & Female & \\
\hline & $\begin{array}{c}\text { Mean } \pm \text { SD } \\
15.10 \pm 11.8\end{array}$ & $\begin{array}{l}\text { Mean } \pm \text { SD } \\
7.93 \pm 7.79\end{array}$ & $\begin{array}{l}\text { Mean } \pm \text { SD } \\
15.64 \pm 13.02\end{array}$ & $\begin{array}{l}\text { Mean } \pm \text { SD } \\
15.72 \pm 10.35\end{array}$ & \\
\hline
\end{tabular}

Table (4): Periodic dental examinations of the study subjects.

\begin{tabular}{|c|c|c|c|c|c|c|}
\hline \multirow{2}{*}{ Items } & \multicolumn{2}{|c|}{$\bar{~}$ Study group } & \multicolumn{2}{|c|}{ Control group } & \multirow{2}{*}{$\mathrm{X}^{2}$} & \multirow{2}{*}{ p-value } \\
\hline & $\mathbf{N}_{=} \mathbf{3 5}$ & $\%$ & $\mathrm{~N}_{=} 35$ & $\%$ & & \\
\hline $\begin{array}{l}\text { Dental visits and frequency: } \\
\text {. Do not visit } \\
. \quad \text { Every six months } \\
. \quad \text { When problem occur }\end{array}$ & $\begin{array}{c}21 \\
0 \\
14\end{array}$ & $\begin{array}{c}60.0 \\
0.0 \\
40.0\end{array}$ & $\begin{array}{c}15 \\
1 \\
19\end{array}$ & $\begin{array}{c}42.9 \\
2.9 \\
54.3\end{array}$ & 2.758 & 0.252 \\
\hline $\begin{array}{l}\text { Reason of not having dental } \\
\text { examination: } \# \\
\begin{aligned} . & \text { Not perceive the need } \\
. & \text { Fear from infection } \\
. & \text { Need for transportation } \\
. & \text { Fear from pain } \\
\text {. } & \text { High costs }\end{aligned}\end{array}$ & $\begin{array}{c}29 \\
2 \\
32 \\
12 \\
21\end{array}$ & $\begin{array}{c}82.9 \\
5.7 \\
91.4 \\
34.3 \\
60.0\end{array}$ & $\begin{array}{c}32 \\
5 \\
29 \\
15 \\
25\end{array}$ & $\begin{array}{l}91.4 \\
14.3 \\
82.9 \\
42.9 \\
71.4\end{array}$ & $\begin{array}{l}1.148 \\
1.429 \\
0.621 \\
0.543 \\
1.014\end{array}$ & $\begin{array}{l}0.284 \\
0.232 \\
0.157 \\
0.461 \\
0.314\end{array}$ \\
\hline $\begin{array}{l}\text { Reason of the last dental examination: } \\
\text {. Teeth extraction } \\
. \quad \text { Teeth filling and cleaning } \\
. \quad \text { Prosthodontic } \\
\text {. } \\
\text { Toothache }\end{array}$ & $\begin{array}{c}\mathbf{N}_{\mathbf{n}} \mathbf{1 4} \\
5 \\
3 \\
2 \\
4\end{array}$ & \begin{tabular}{c|}
$\%$ \\
35.7 \\
21.4 \\
14.3 \\
28.6
\end{tabular} & $\begin{array}{c}\mathbf{N}_{\mathbf{n}} \mathbf{2 0} \\
9 \\
3 \\
4 \\
4\end{array}$ & \begin{tabular}{c|}
$\mathbf{\%}$ \\
45.0 \\
15.0 \\
20.0 \\
20.0
\end{tabular} & 4.192 & 0.522 \\
\hline
\end{tabular}


Table (5): Oral self care practices of the study subjects in both groups.

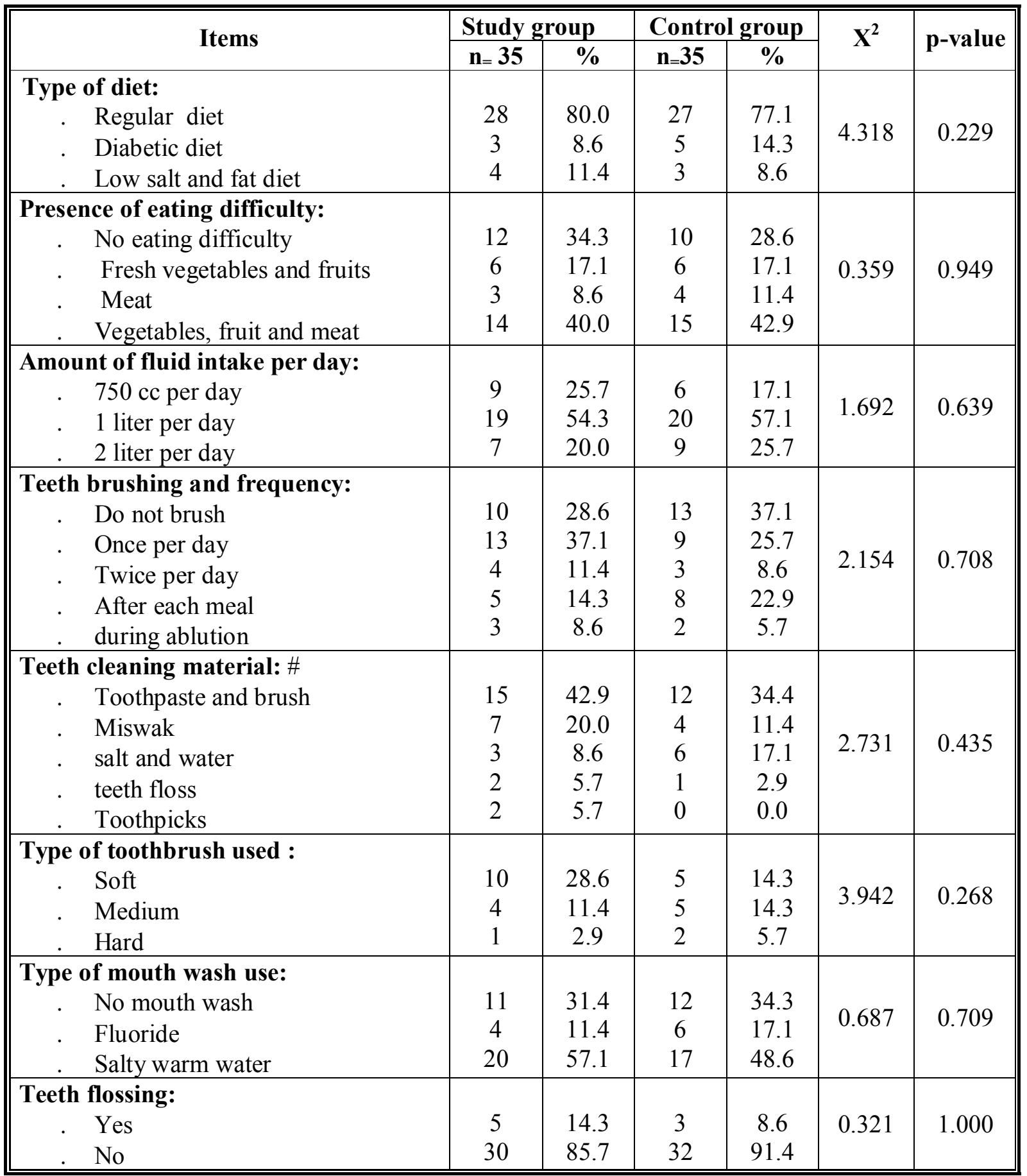

*Significant, at $\mathrm{P} \leq 0.05$, using Chi-Square $\left(\mathrm{X}^{2}\right)$. 
Table (6): Oral self care practice observational checklists of the study subjects before the intervention and for the study group after the interventio

\begin{tabular}{|c|c|c|c|c|c|c|c|c|c|c|c|c|c|c|}
\hline \multicolumn{15}{|c|}{ Oral self care observational checklists } \\
\hline \multirow{4}{*}{$\begin{array}{l}\text { Oral self care } \\
\text { practices } \\
\text { procedures }\end{array}$} & \multicolumn{6}{|c|}{ Study group $n_{=}(35)$} & \multicolumn{6}{|c|}{ Control group $n_{=}(35)$} & & \\
\hline & \multicolumn{3}{|c|}{$\begin{array}{c}\text { Before the intervention } \\
n_{=}(35)\end{array}$} & \multicolumn{3}{|c|}{$\begin{array}{c}\text { Immediately after the } \\
\text { intervention } \\
n=(35)\end{array}$} & \multicolumn{3}{|c|}{$\begin{array}{l}\text { Before the intervention } \\
\qquad \mathbf{n}=\mathbf{( 3 5 )}\end{array}$} & \multicolumn{3}{|c|}{$\begin{array}{c}\text { Immediately after the } \\
\text { intervention } \\
n=(35)\end{array}$} & \multirow{2}{*}{\multicolumn{2}{|c|}{$\begin{array}{c}\text { Test of } \\
\text { significant }\end{array}$}} \\
\hline & $\begin{array}{c}\text { Completely } \\
\text { manage }\end{array}$ & $\begin{array}{l}\text { Partially } \\
\text { manage }\end{array}$ & $\begin{array}{l}\text { Unable to } \\
\text { manage }\end{array}$ & $\begin{array}{c}\text { Completely } \\
\text { manage }\end{array}$ & $\begin{array}{c}\text { Partially } \\
\text { manage }\end{array}$ & $\begin{array}{c}\text { Unable to } \\
\text { mange }\end{array}$ & $\begin{array}{c}\text { Completely } \\
\text { mange }\end{array}$ & $\begin{array}{l}\text { Partially } \\
\text { manage }\end{array}$ & $\begin{array}{l}\text { Unable to } \\
\text { manage }\end{array}$ & $\begin{array}{c}\text { Completely } \\
\text { manage }\end{array}$ & $\begin{array}{l}\text { Partially } \\
\text { manage }\end{array}$ & $\begin{array}{c}\text { Unable to } \\
\text { manage }\end{array}$ & & \\
\hline & $\mathbf{N}(\%)$ & $\mathbf{N}(\%)$ & $\mathbf{N}(\%)$ & $\mathbf{N}(\%)$ & $\mathbf{N}(\%)$ & $\mathbf{N}(\%)$ & $\mathbf{N}(\%)$ & $\mathbf{N}(\%)$ & $\mathbf{N}(\%)$ & $\mathbf{N}(\%)$ & $\mathbf{N}(\%)$ & $\mathbf{N}(\%)$ & $(\mathbf{p})^{1}$ & $(\mathbf{p})^{2}$ \\
\hline \multirow[t]{3}{*}{ Teeth brushing } & $0(0.0)$ & $9(25.7)$ & $26(74.3)$ & $16(45.7)$ & $19(54.3)$ & $0(0.0)$ & $0(0.0)$ & $12(34.3)$ & $23(65.7)$ & $0(0.0)$ & $11(31.4)$ & $24(68.6)$ & 0.301 & $0.000^{*}$ \\
\hline & \multicolumn{3}{|c|}{$\mathrm{Z}_{=}=-5.052$} & \multicolumn{3}{|l|}{$\mathrm{P}=0.000^{*}$} & \multicolumn{6}{|c|}{$\begin{array}{cc}Z_{=}=-1.000 & P_{=}=0.317 \\
\end{array}$} & & \\
\hline & \multicolumn{3}{|r|}{$(4.51 \pm 2.39)$} & \multicolumn{3}{|l|}{ Mean $\pm \mathrm{SD}$} & \multicolumn{3}{|l|}{ Mean \pm SD } & \multicolumn{3}{|l|}{ Mean \pm SD } & & \\
\hline \multirow{4}{*}{ Teeth flossing } & & & & & & & & & & & & & & \\
\hline & $0(0.0)$ & $3(8.6)$ & $32(91.4)$ & $12(34.3)$ & $23(65.7)$ & $0(0.0)$ & $0(0.0)$ & $3(8.6)$ & $32(91.4)$ & $1(2.9)$ & $4(11.4)$ & $30(85.7)$ & 0.663 & $0.000^{*}$ \\
\hline & \multicolumn{3}{|r|}{$\mathrm{Z}=-5.445$} & \multicolumn{3}{|l|}{$\mathrm{P}=0.000^{*}$} & \multirow{2}{*}{\multicolumn{3}{|c|}{$\begin{array}{r}Z_{=}-1.342 \\
(2.63 \pm 1.61)\end{array}$}} & \multicolumn{3}{|c|}{$\mathrm{P}=0.180$} & & \\
\hline & \multicolumn{3}{|r|}{$(3.51 \pm 1.70)$} & Mean \pm SD & \multicolumn{2}{|c|}{$(11.31 \pm 2.23)$} & & & & \multicolumn{3}{|r|}{$(3.01 \pm 2.83)$} & & \\
\hline \multirow{3}{*}{$\begin{array}{l}\text { Oral cancer self } \\
\text { examination }\end{array}$} & $0(0.0)$ & $0(0.0)$ & $35(100)$ & $8(22.9)$ & $27(77.1)$ & $0(0.0)$ & $0(0.0)$ & $1(2.9)$ & $34(97.1)$ & $0(0.0)$ & $2(5.7)$ & $33(94.3)$ & 0.500 & $0.052 *$ \\
\hline & \multicolumn{3}{|r|}{$Z_{=}=-5.477$} & \multicolumn{3}{|l|}{$\mathrm{P}=0.000^{*}$} & \multicolumn{6}{|c|}{$Z_{=}=-2.000 \quad P=0.146$} & & \\
\hline & Mean $\pm \mathrm{SD}$ & & $0.00 \pm 0.00)$ & Mean $\pm \mathrm{SD}$ & $(16$ & $11 \pm 3.86)$ & Mean \pm SL & & $(2.46 \pm 1.95)$ & Mean \pm SD & & $2.34 \pm 1.49)$ & & \\
\hline
\end{tabular}

* Significant $\mathrm{P}<0.05$

Using Chi-Square $\left(\mathrm{X}^{2}\right)$ in comparing between study and control group in each oral self care practice procedures

(Before the intervention versus immediately after the intervention)

- $\quad$ Using Wilcoxon Signed Ranks Z Test in comparing in each group in each oral self care practice procedures

(Before the intervention versus immediately after the intervention) 
Table (7): The total mean score of the oral health knowledge of the study subjects before the intervention and for the study group after the intervention.

\begin{tabular}{|c|c|c|c|}
\hline \multirow[t]{3}{*}{ Time } & \multicolumn{2}{|c|}{$\begin{array}{c}\text { The total mean score of the oral } \\
\text { health knowledge }\end{array}$} & \multirow{3}{*}{$\begin{array}{c}\text { Test of } \\
\text { significan }\end{array}$} \\
\hline & $\begin{array}{c}\text { The study group } \\
n=(35)\end{array}$ & $\begin{array}{l}\text { The control group } \\
n=(35)\end{array}$ & \\
\hline & Mean \pm SD & Mean \pm SD & \\
\hline Before the intervention & $8.43 \pm 4.70$ & $7.66 \pm 4.76$ & 0.497 \\
\hline Immediately after the intervention & $40.31 \pm 15.03$ & $7.63 \pm 4.81$ & \multirow[b]{2}{*}{$0.000^{*}$} \\
\hline $\begin{array}{c}\text { Before versus immediately after } \\
\text { in each group }\end{array}$ & $\mathrm{P}=(0.000)^{*}$ & $\mathrm{P}=(0.661)$ & \\
\hline Three month after the intervention & $25.60 \pm 11.96$ & $7.74 \pm 4.78$ & \multirow[b]{2}{*}{$0.000 *$} \\
\hline $\begin{array}{c}\text { Before versus after } 3 \text { months } \\
\text { in each group }\end{array}$ & $\mathrm{P}_{=}(0.000)^{*}$ & $\mathrm{P}_{=}(0.083)$ & \\
\hline Six month after the intervention & $19.80 \pm 9.56$ & $7.80 \pm 4.81$ & \multirow[b]{2}{*}{$0.000^{*}$} \\
\hline $\begin{array}{c}\text { Before versus after } 6 \text { months } \\
\text { in each group }\end{array}$ & $\mathrm{P}_{=}(0.000)^{*}$ & $P_{=}(0.096)$ & \\
\hline
\end{tabular}

Table (8): Oral self care practices of the study subjects before the intervention and for the study group after the intervention.

\begin{tabular}{|c|c|c|c|}
\hline \multirow[t]{3}{*}{ Time } & \multicolumn{2}{|c|}{$\begin{array}{l}\text { The total mean score of the oral } \\
\text { self care practices of the study } \\
\text { subjects }\end{array}$} & \multirow{3}{*}{$\begin{array}{c}\text { Test of } \\
\text { significant }\end{array}$} \\
\hline & $\begin{array}{l}\text { The study } \\
\text { group } \\
n=(35)\end{array}$ & $\begin{array}{l}\text { The control } \\
\text { group } \\
n=(35) \\
\end{array}$ & \\
\hline & Mean \pm SD & Mean \pm SD & \\
\hline Before the intervention & $4.97 \pm 2.49$ & $5.20 \pm 2.96$ & $(p)^{1}=0.728$ \\
\hline Three month after the intervention & $13.86 \pm 4.75$ & $5.46 \pm 2.67$ & \multirow[b]{2}{*}{$(p)^{2}=0.000^{*}$} \\
\hline $\begin{array}{l}\text { Before versus after } 3 \text { months } \\
\text { in each group }\end{array}$ & $\mathrm{P}=0.000^{*}$ & $\mathrm{P}=0.152$ & \\
\hline Six month after the intervention & $11.03 \pm 4.06$ & $5.43 \pm 2.68$ & \multirow[b]{2}{*}{$(p)^{3}=0.000^{*}$} \\
\hline $\begin{array}{l}\text { Before versus after } 6 \text { months } \\
\text { in each group }\end{array}$ & $\mathrm{P}=0.000^{*}$ & $\mathrm{P}=0.199$ & \\
\hline
\end{tabular}

* Significant $\mathrm{P}<0.05$

Using Chi-Square $\left(\mathrm{X}^{2}\right)$ in comparing between both groups

Using student T-test in comparing in each group. 
Table (9): Relation between the sciodemographic characteristics of the subjects in the study group and their total mean score of oral self care practices before and after the study intervention.

\begin{tabular}{|c|c|c|c|c|c|c|}
\hline \multirow{3}{*}{$\begin{array}{c}\text { Sciodemographic } \\
\text { characteristics } \\
\text { Items }\end{array}$} & \multicolumn{6}{|c|}{$\begin{array}{c}\text { Total mean score of the oral self care practices of the } \\
\text { study group } n_{=}(35)\end{array}$} \\
\hline & \multicolumn{2}{|c|}{$\begin{array}{l}\text { Before the } \\
\text { intervention }\end{array}$} & \multicolumn{2}{|c|}{$\begin{array}{l}\text { Three months after } \\
\text { the intervention }\end{array}$} & \multicolumn{2}{|c|}{$\begin{array}{c}\text { six months after the } \\
\text { intervention }\end{array}$} \\
\hline & (n) & Mean \pm SD & (n) & Mean \pm SD & (n) & Mean \pm SD \\
\hline \multicolumn{7}{|l|}{ Age (in year) } \\
\hline \multirow{3}{*}{$\begin{array}{ll} & 60- \\
\cdot & 75- \\
. & 85+\end{array}$} & 29 & $4.75 \pm 3.30$ & 29 & $13.50 \pm 6.36$ & 29 & $11.00 \pm 5.66$ \\
\hline & 4 & $4.79 \pm 2.41$ & 4 & $13.75 \pm 3.40$ & 4 & $11.10 \pm 4.20$ \\
\hline & 2 & $4.00 \pm 0.00$ & 2 & $12.35 \pm 4.90$ & 2 & $10.50 \pm 2.38$ \\
\hline $\begin{array}{l}\text { Test of } \\
\text { significance }\end{array}$ & \multicolumn{2}{|c|}{$\mathrm{F}_{=}=1.265, \quad \mathrm{P}=0.296$} & \multicolumn{2}{|c|}{$\mathrm{F}=0.425, \quad \mathrm{p}=0.658$} & \multicolumn{2}{|c|}{$\mathrm{F}_{=}=0.509, \mathrm{p}=0.606$} \\
\hline \multicolumn{7}{|l|}{ Sex } \\
\hline \multirow{2}{*}{$\begin{array}{l}\text { Males } \\
\text { Females }\end{array}$} & 19 & $4.31 \pm 2.44$ & 19 & $13.72 \pm 4.50$ & 19 & $11.47 \pm 4.71$ \\
\hline & 16 & $3.69 \pm 2.40$ & 16 & $9.81 \pm 2.95$ & 16 & $9.31 \pm 2.24$ \\
\hline $\begin{array}{l}\text { Test of } \\
\text { significance }\end{array}$ & \multicolumn{2}{|c|}{$\mathrm{T}=0.613, \quad \mathrm{P}=0.544$} & \multicolumn{2}{|c|}{$\mathrm{T}=4.421, \quad \mathrm{P}=0.000^{*}$} & \multicolumn{2}{|c|}{$\mathrm{T}=2.598, \mathrm{P}=0.015^{*}$} \\
\hline \multicolumn{7}{|l|}{$\begin{array}{l}\text { Level of } \\
\text { education }\end{array}$} \\
\hline \multirow{4}{*}{$\begin{array}{ll} & \text { Illiterate } \\
. & \text { Primary } \\
\text { education } \\
\text {. } & \text { Secondary } \\
\text { education } \\
\text {. } & \text { University } \\
\text { education }\end{array}$} & 11 & $3.55 \pm 1.13$ & 11 & $8.18 \pm 1.54$ & 11 & $8.15 \pm 2.69$ \\
\hline & 8 & $4.63 \pm 2.13$ & 8 & $10.50 \pm 2.30$ & 8 & $9.00 \pm 3.12$ \\
\hline & 6 & $4.50 \pm 2.28$ & 6 & $12.33 \pm 2.33$ & 6 & $11.50 \pm 3.27$ \\
\hline & 10 & $5.50 \pm 2.32$ & 10 & $13.50 \pm 2.34$ & 10 & $13.50 \pm 3.36$ \\
\hline $\begin{array}{l}\text { Test of } \\
\text { significance }\end{array}$ & \multicolumn{2}{|c|}{$\mathrm{F}=3.074, \quad \mathrm{P}=0.142$} & \multicolumn{2}{|c|}{$\mathrm{F}=20.743, \mathrm{P}=0.000 *$} & \multicolumn{2}{|c|}{$\mathrm{F}=11.078, \mathrm{P}=0.000^{*}$} \\
\hline \multicolumn{7}{|l|}{ Marital status: } \\
\hline \multirow{3}{*}{$\begin{array}{ll}\text {. } & \text { Widowed } \\
\text {. } & \text { Divorced } \\
\text {. } & \text { Separated }\end{array}$} & 25 & $4.18 \pm 2.29$ & 25 & $12.84 \pm 4.43$ & 25 & $10.36 \pm 3.14$ \\
\hline & 5 & $4.20 \pm 2.28$ & 5 & $13.40 \pm 4.57$ & 5 & $10.20 \pm 4.31$ \\
\hline & 5 & $4.70 \pm 2.30$ & 5 & $12.40 \pm 4.43$ & 5 & $11.20 \pm 3.96$ \\
\hline $\begin{array}{l}\text { Test of } \\
\text { significance }\end{array}$ & \multicolumn{2}{|c|}{$\mathrm{F}=0.272, \mathrm{P}=0.763$} & \multicolumn{2}{|c|}{$\mathrm{F}=2.409, \quad \mathrm{P}=0.106$} & \multicolumn{2}{|c|}{$\mathrm{F}=3.539, \mathrm{P}=0.141$} \\
\hline \multicolumn{7}{|l|}{ Monthly income } \\
\hline \multirow{3}{*}{$\begin{array}{ll} & 200<300 \\
. & 300<400 \\
. & 400+ \\
\end{array}$} & 5 & $3.50 \pm 1.29$ & 5 & $8.50 \pm 3.11$ & 5 & $6.75 \pm 2.99$ \\
\hline & 4 & $3.80 \pm 1.84$ & 4 & $11.80 \pm 3.84$ & 4 & $10.40 \pm 3.14$ \\
\hline & 26 & $4.28 \pm 2.55$ & 26 & $13.08 \pm 4.04$ & 26 & $12.81 \pm 4.19$ \\
\hline $\begin{array}{l}\text { Test of } \\
\text { significance }\end{array}$ & \multicolumn{2}{|c|}{$\mathrm{F}=3.839, \quad \mathrm{P}=0.132$} & \multicolumn{2}{|c|}{$\mathrm{F}=4.707, \quad \mathrm{P}=0.016^{*}$} & $\mathrm{~F}=3$ & $=0.059 *$ \\
\hline
\end{tabular}


Table (10): Correlation between the oral health knowledge and the oral self care practices of subjects in the study group before and after the study intervention.

\begin{tabular}{|c|c|c|c|c|}
\hline $\begin{array}{c}\text { The total mean score } \\
\text { of the oral self care } \\
\text { practices }\end{array}$ & Mean \pm SD & $\begin{array}{l}\text { The total mean score of } \\
\text { the oral health knowledge }\end{array}$ & Mean \pm SD & $\mathbf{r}=$ \\
\hline -Before the intervention & $(4.97 \pm 2.49)$ & - Before the intervention & $(8.43 \pm 4.70)$ & $\begin{array}{l}0.401 * * \\
(0.017)\end{array}$ \\
\hline $\begin{array}{l}\text {-Three months after the } \\
\text { intervention }\end{array}$ & $(13.86 \pm 4.7)$ & $\begin{array}{l}\text {-Three months after the } \\
\text { intervention }\end{array}$ & $\begin{array}{c}(25.60 \pm 11.96 \\
)\end{array}$ & $\begin{array}{l}0.854^{* *} \\
(0.000)\end{array}$ \\
\hline $\begin{array}{l}\text {-Six months after the } \\
\text { intervention }\end{array}$ & $(11.03 \pm 4.0)$ & $\begin{array}{l}\text {-Six months after the } \\
\text { intervention }\end{array}$ & $(19.80 \pm 9.56)$ & $\begin{array}{l}0.770^{* *} \\
(0.000)\end{array}$ \\
\hline
\end{tabular}

** Correlation is significant at the 0.01 level (2-tailed). 


\section{References}

1. Theris A \& Kathleen F. Ebersole and Hess' Gerontological Nursing Healthy Aging. $3^{\text {rd }}$ ed. Mosby Company, 2010: 107-9.

2. Ship JA. Improving Oral Health in Older People. The American Geriatrics Society; 2002; 50 (8): 1454-55.

3. Singha K, Kochhar S, Mittal V, Agrawal A, Chaudhary H \& Anandani C. Oral health: Knowledge, Attitude and Behavior among Indian Population. Educational Research. 2012; 3(1) pp. 066-071 Retrieved on June 11, 2013 from:

http://www.interesjournals.org/ER.

4. Patricia A \& Perry A. Fundamentals of Nursing, $6^{\text {th }}$ ed, Mosby Company: 2005: 1041-47.

5. Visschere LD, Schols J, Vanobbergen J, Augsburger H. Study Protocol Health Care Guideline in (Residential) Care Homes $\square$ : A Cluster BMC Oral Health. 2010; 0-19. Doi: 10.1186/1472-6831-1017.

6. World Health Organization. What is Oral Health? Fact sheet. 2007: Geneva: WHO.

7. Naito M, Kato T, Fujii W, Ozeki M, Yokoyama $\mathrm{M}$ and Saitoh E. Effects of Dental Treatment on the Quality of Life and Activities of Daily Living in Institutionalized Elderly in Japan. Arch Gerontol Geriatr.2010; 50:65- 68.

8. Jablonski RA. Mouth Care in Nursing Homes: Knowledge, Beliefs, and Practices of Nursing Assistants. Geriatric Nursing. 2009; 30(2):99-107.

9. Slaughter L \& Evans T. Culturally Sensitive Oral Health Educational Materials for Older African Americans. J Health Care Poor Underserved: 2007; 18: 868-886.

10. Younget Al. Care Home Staff Knowledge of Oral Care Compared to
Best Practice: a West of Scotland. Pilot Study. British Dental Journal. 2009; 205: 450-451.

11. Folstein M \& Folstein SE. "Mini-Mental State" A practical Method for Grading the Cognitive State of Patients for the Clinician. J of Psychiatric Research, 1975; 12(3):189-98: Retrieved on May 13, 2011 from: http//www.hartfordign.org.

12. El Okel M. Prevalence of Alzheimer Dementia and Other Causes of Dementia in Egyptian Elderly. Unpublished Master Thesis. Faculty of Medicine. Ain Shams University; 2002.

13. Foreman MD \& Fletcher K. Assessing Cognitive Function. Geriatric Nursing J. 1996; 17:228-33.

14. Sheikh JI \& Yesavage JA. Geriatric Depression Scale (GDS). Recent Evidence and Development of A shorter Version. Clinical Gerontology J: A Guide to Assessment and Intervention. 1986; (165-173). Retrieved on May 17, 2011 from: http://www.stanford.edu/ yesavage/GD S.html.

15. El Elhuseiny S. Effect of Self Care Interventions on the Quality Of Life of Older Adults with Heart Failure. Unpublished Doctorate Thesis, Phd, Alexandria: University of Alexandria, Faculty of Nursing; 2013.

16. The Oral Cancer Exam. National Cancer Institute, National Institute of Dental and Craniofacial Research; 2008 available at: http://www.nided.nih.gov.

17. Marcenes WA, Sanders AE, Slade GD, Turrell G \& Spencer AJ. The Shape of the Socioeconomic Oral Health Gradient: Implication for Theoretical explanations. Community Dentistry and Oral Epidemiology.2006; 34(4):310319. 
18. Penner A \& Timmons V. Seniors' Attitudes: Oral Health and Quality Of Life Int J Dent. Hygiene: 2004; 2; 2-7.

19. Hawash M. Assessment of Oral Health Status for the Residents of Elderly Homes. Published thesis, Master degree. Alexandria: Faculty of nursing: 2006; 1 2.

20. Shamdol Z, Ismail AR \& Hamzah NT. Prevalence of Dentate Elderly and the Relationship of Number of Remaining Teeth and Oral Health Related Quality of Life of Older Adults in Kota Bharu Kelantan, Malaysia. International Medical Journal. 2009; 16 (1): 65-6.

21. Al-Shehri SH. Oral Health Status of Older People in Residential Homes in Saudi Arabia: Open Journal of Stomatology: 2012; 307-313. doi:10.4236/ojst.2012.24053 published Online December 2012 Available at: http://www.SciRP.org/journal/ojst/.

22. Juliana O. Taiwo J, Ibiyemi O, Bankole O. Oral Health Attitudes and Practices of the Older Adults in South East Local Government Area (SELGA) In Ibadan. Journal of Biology, Agriculture and Healthcare. 2012; ISSN 2224-3208 (Paper) ISSN 2225-093X.

23. Abdel-Hamied S. Self Care Practice among Home Based Diabetic Elderly In Dakahlia Governorate. Unpublished Thesis; Faculty of Nursing, Alexandria University; 2005.

24. Uludamar A, Evren B, Iseri U, Ozkan Y. Oral Health Status and Treatment Requirements of Different Residential Homes in Istanbul: A Comparative Study; Arch Gerontol Geriatr. 2011; 53: 67-74.

25. Elhusseini S. Factors related to self care capabilities among institutionalized elders, Unpublished Master Thesis, Faculty of Nursing, Alexandria, Egypt; 2008.
26. Branch LG \& Jette AM. A prospective Study of Long-Term Care Institutionalization among the Aged. Am. J. Public Health. 1982; 72(12):1373-9.

27. Christensen L, Hede1 B \& Nielsen E. A Cross-Sectional Study of Oral Health and Oral Health-Related Quality of Life Among Frail Elderly Persons on Admission to A Special Oral Health Care programme in Copenhagen City, Denmark: The Gerodontology Society and John Wiley \& Sons: 2012; A/S; 29: e392-e400.

28. Nazliel HE, Hersek N \& Ozbek M. Oral Health Status in a Group of the Elderly Population Residing at Home. Gerodontology 2012; 29: e761-e767.

29. Hamza A, Ahmed A \& Waseef A. Subjective Oral Health Status Indicators and Their Relation to Nutritional Status among Institutionalized Elderly. Egyptian Dental Journal: 1999; 45(1): 4369-89.

30. Hassan M. Subjective Oral Health Status Indicators and Their Relation to Nutritional Status among Institutionalized Elderly in Alexandria Egyptian Dental Journal: 1999; 45(1). Retrieved on 28 January 2013, Available at King Abdulaziz University, Faculty of Dentistry Website.

31. Hämäläinen $\mathrm{P}$, Meurman $\mathrm{JH}$, Keskinen M \& Heikkinen E. Relationship between Dental Health and 10-Year Mortality in A Cohort of Community Dwelling Older Adults. Eur J Oral Sc: 2003; (111): 291 296.

32. Suominen-Taipale AL, Nordblad A, Alanen P, Alha P\& Koskinen S. SelfReported Dental Health, Treatment Need and Attendance among Older Adults in Two Areas of Finland. Community Dent Health: 2011; 18: 20-26.

33. Zhu L, Petersen PE, Wang HY, You Bian J, Zhang BX. Oral Health Knowledge, Attitudes and Behavior of 
adults In China. Int. Dent. J: 2005; 55: 231-241.

34. Marchini L, Vieira PC \& Bossan TP. "Self-reported Oral Hygiene Habits among Institutionalized Elderly and Their Relationship to the Condition of Oral Tissues in Taubaté, Brazil." Gerodontology J: 2006; 23(1): 33-37.

35. Abo El-Azm SH. Elderly's Knowledge of Dental Health and Oral Hygiene Practices and Their Relation to Oral Health Conditions. Unpublished Thesis, Master of Public Health Nursing, Higher Institute of Nursing, Alexandria University; Egypt; 1986.

36. Fiske J. The Delivery of Oral Care Services to Older adults living in a Non Institutionalized Setting. J Public health dent: 2010; 60: 321-325.

37. Cheung C, Tong $M$ \& Lum C. Effectiveness of an Oral Health Care education Programme Delivered by Elderly Ambassadors: A QuasiRandomized controlled trial, Asian J Gerontol Geriatr: 2006; 1:5-13.

38. Zini A, Slutzky H \& Vered Y. Intervention Plan for Improving Oral Health among the Elderly Residing in the Community and in A Nursing Home, Middle East Journal of Age and Ageing: 2013; 10(1):13-16. Retrieved on January 2013-07-18.

39. Shamsi M, Hidarnia A \& Niknami S. Self-Reported Oral Hygiene Habits and Self-Care in the Oral Health in Sample of Iranian Women during Pregnancy, Middle-East Journal of Scientific Research:2013; 13 (1): 91-100.

40. Leili S, Elham S \& Farkhonde S. A population-Based Survey of HIV/AIDS Knowledge and Attitudes in General public, Bandar-Abbas, Iran. Pak. J. Med. Sci: 2008; 24 (4): 838-44.

41. Polychronopoulou A \& Kawamura M. Oral self-care behavior: comparing
Greek and Japanese dental Students. Eur. J. Dent. Educ.: 2005; 9 (4): 164 170.

42. Saito A, Kikuchi M \& Ueshima F. Assessment of Oral Self-Care in Patients with Periodontitis: A pilot Study in A dental School Clinic in Japan. BMC Oral Health: 2009; 9:27 doi: 10.1186/14726831-9-27.

43. Ribeiro DG, Jorge JH \& Varjao FM. Evaluation of Partially Dentate Patients' Knowledge about Caries and Periodontal Disease. Gerodontology: 2011; doi: 10.1111/j.1741-2358.2011.00460.X.

44. Komulainen K, Ylöstalo P \& Syrjälä AM. Oral Health Intervention among Community-Dwelling Older People: A Randomized 2-Year Intervention Study. Gerodontology: 2013; Jul 10. Doi: 10.1111/Ger.12067. Research Centre of Geriatric Care, University Of Eastern Finland, Kuopio, Finland.

45. De Sousa N, Bezerra ML\& Ramos AS. Self-Care in Oral Health in the Third Age: Report of an Elderly Group. Journal of Nursing UFPE / Revista de Enfermagem: 2012; (6):11, p 2649.

46. Artnik B, Premik M \& Kragelj L. Population Groups at High Risk for Poor Oral Self Care: The Basis for Oral Health Promotion Int J Public Health: 2008; 53; 195- 203.

47. Vyšniauskaite S, Kammona N \& Vehkalahti M. Number of Teeth in Relation to Oral Health Behaviors in Dentate Elderly Patients in Lithuania. The Gerodontology Association and Blackwell Munksgaard Ltd, Gerodontology: 2005; 22: 44-51.

48. Abdullah M, Ali H \& Rahiman SH. Knowledge, Practice and Awareness of Oral Hygiene among Three Different Age Populations of Same Ethnic Group a Community Based Study. Braz J Oral Sci: 2010; 4 (9). 